\title{
Detection of shiga toxin producing Escherichia coli isolated from children and cattle using PCR technique
}

\author{
H. N. A'aiz F. A. Abdulla A. H. Al- Hamadani
}

Abstract

This study was undertaken to detect STEC isolates, gene $\left(S_{t} x_{2}\right)$ in Escherichia coli isolates and characterize them by biochemical tests, enterohemolysin production and PCR.During a period of seven months (November 2007 to May 2008), a total of 280 fecal samples were collected from 120 hospitalized children suffering from diarrhea and 160 cattle fecal samples . Feces specimens were screened for the presence of NSF E. coli and STEC by cultured on sorbitol MacConkey agar (SMAC).A total of 209 (74.6\%) non-sorbitol fermenting (NSF) bacterial isolates were obtained , $69(57.5 \%)$ from children fecal samples and $140(87.5 \%)$ from cattle feces. Of which $5(4.16 \%)$ NSF E. coli isolated from children fecal samples and 38 $(23.75 \%)$ from cattle feces. NSF isolates were identified as Shiga toxin producing E. coli (STEC), but only $16(10 \%)$ isolates of cattle and $2(1.6 \%)$ isolates of children were PCR-positive for $\left(S t x_{2}\right)$ gene which gave amplification bands at $346 \mathrm{bp}$ using DNA marker in the interpretation of the results. Among 18 STEC studied, a total of $16(88.8 \%)$ isolates expressed enterohemolysin on whing sheep blood agar plates. On the other hand, the study was showed that the sensitivity and specificity of PCR technique in diagnosis of STEC were $41.8 \%, 100 \%$ respectively, in comparison with other tests like biochemical tests, sensitivity and specificity of these tests were $(100 \%, 86.9 \%)$ respectively.

\section{Introduction}

Diarrheal disease remains as a major public health problem in developing countries (1).E. coli classified on the basis of their virulence properties, mechanisms of pathogenicity, clinical symptoms and the presence of distinct $\mathrm{O}$ and $\mathrm{H}$ antigens (2).Groupings include ; enterotoxogenic $E$. coli (ETEC), Shiga toxin producing E. coli (STEC), Enteroaggrehative $E$. coli (EAggEC), enteropathogenic E. coli (EPEC), enteroinvasive E. coli (EIEC) and diffuse-adhering E. coli (DAEC) these group are associated with diarrhea, hemorrhagic colitis (HC); dysentery; bladder and kidney infection; surgical wound infection; septicemia; hemolytic uraemic syndrome (HUS) pneumonia and meningitis, some of these condition result in death.Pioneering work in the 1970 demonstrated that certain E.coli strains produced a toxin, which was

\section{Materials and methods}

\section{Samples collection}

One hundred and twenty of stool samples were collected from children under 5 years old from both sexes suffering from initially called verocytotoxin because of its distinct effect on vero cells ( 3 ). This family of toxin was subsequently also called shiga like toxin and was recently shiga toxin (stx) because of the close relation to (stx) of shigella dysenteriae type 1 . Verocytotoxin producing $E$. coli belonging to several different $\mathrm{O}$ serotype, has been associated with watery or bloody diarrhea, hemorrhagic colitis (HC) hemolytic uremic syndrome (HUS) (4). E. coli O157:H7 has emerged as a major food - borne zoonotic pathogen in human (5). The severity of the disease and occurrence of several outbreaks in worldwide which result from consumption of contaminated food with this bacteria lead to focusing of many researches to development the efficiency of diagnostic methods for this bacteria (6).

diarrhea who attending to the Teaching Hospital of Gynecology and pediatric in AlDiwanyia city during the period from November 2007 to April 2008. A small 
sample of stool was injected in to $5 \mathrm{ml}$ of TSB-CV and transported to the laboratory.On the other hand, the fecal samples (160) were collected from slaughter and alive cattle of different ages and sexes (80 for each) during the period from November 2007 to May 2008 in Diwanyia and Najaf provinces. Fecal samples were obtained from cattle in Al-Diwanyia abattoir and Al-Bahrany cattle farmers in Al-Najaf and transported in sterile container to the laboratory.

\section{Isolation of STEC}

Culturing of broth was performed on sorbitol MacConkey agar (SMAC), which is composed of $1 \%$ sorbitol instead of lactose in standard MacConkey agar, this medium supplemented with cefixime $\left(0.05 \mathrm{mg} / 1^{-1}\right)$, potassium tellurite $\left(2.5 \mathrm{mg} / 1^{1}\right)$ and rhamnose $\left(5 \mathrm{~g} / 1^{-1}\right)$ to become selective (SMAC-CTR ) for STEC (7). This medium was used to identify sorbitol fermenter and non-fermenter colonies after incubation at 37 ${ }^{\circ} \mathrm{C}$ for overnight. Sorbitol negative colonies (colonies grow colorless) were transferred to MacCokey agar plates, incubated for additional overnight to identify lactose fermentation .

\section{Enterohemolysin test}

Enterohemolysin activity of the isolates was detected on tryptose agar plates supplemented with $0.11 \% \mathrm{CaCl}_{2}$ and $5 \%$ defibrinated washed sheep blood (8). The inoculated plates were observed for hemolysis after $8 \mathrm{hrs}$ of incubation for detection of $\alpha$-hemolysis and after overnight incubation at $37{ }^{\circ} \mathrm{C}$ for detection enterohemolysis.

\section{Cellobiose fermentation test}

Cellobiose fermentation broth was inoculated with a young colony and incubated at $37{ }^{\circ} \mathrm{C}$ for $24 \mathrm{hrs}$. Fermentation test was considered positive when color of broth was changed to yellow (9).

\section{Potassium cyanide (KCN) test}

Potassium cyanide broth was inoculated with one loopful a colony culture and incubated at $37{ }^{\circ} \mathrm{C}$ with the cap tightly screwed down to prevent air exchange. Growth (turbidity) after 24-48 hrs indicated a positive result (10).

\section{Method of PCR reaction (for $V T 2$ gene detection)}

Detection of chromosome encoded virulence gene (E. coli VT2) was done using primers by thermal cycler. The PCR amplification mixture for the detection of VT2 contained $25 \mu \mathrm{l}$ of green master mix (which contains bacterially derived Taq DNA polymerase, dNTPs, $\mathrm{MgCl}_{2}$ and reaction buffer at optimal concentration for efficient amplification of DNA templates by PCR), $5 \mu \mathrm{l}$ of DNA, $2.5 \mu \mathrm{l}$ of each forward and reverse primers , $15 \mu \mathrm{l}$ of nuclease-free water and $20 \mu \mathrm{l}$ of mineral oil.The results of the PCR were performed in post amplification area. $10 \mu \mathrm{l}$ from amplification samples was directly loaded in a $2 \%$ agarose gel containing $0.5 \mu \mathrm{l} / 25 \mathrm{ml}$ ethidium bromide with adding loading buffer in electrophoresis and the products were visualized by UV transillumination .

\section{Results}

Biochemical examination for NSF isolates revealed that the $4.16 \%$ of isolates in children were STEC while in cattle $23.75 \%$ of isolates were STEC . A statistical analysis revealed a significant differences ( $p$
$<0.01)$ between positive and negative results in diagnosis of STEC depend on biochemical tests in children and cattle (Table 1). 
Table 1 : Number and percentage of STEC isolates.

\begin{tabular}{|l|c|c|c|c|l|l|l|}
\hline $\begin{array}{c}\text { Isolates } \\
\text { Sources }\end{array}$ & $\begin{array}{c}\text { NO. of } \\
\text { samples }\end{array}$ & $\begin{array}{c}+ \text { ve } \\
\text { isolates }\end{array}$ & $\%$ & $\begin{array}{c}\text {-ve } \\
\text { isolates }\end{array}$ & $\%$ & $X^{2}$ & P-value \\
\hline Children & 120 & 5 & 4.16 & 115 & 95.84 & 81.99 & $0.01 *$ \\
\hline Cattle & 160 & 38 & 23.75 & 122 & 76.25 & 27.04 & 0.01 \\
\hline Total & 280 & 43 & 15.36 & 237 & 84.64 & \multicolumn{2}{c|}{$\mathrm{df}=1$} \\
\hline
\end{tabular}

$* \mathrm{p}<0.01$

\section{Biochemical identification of STEC from other Escherichia Spp.}

The differentiation between NSF STEC and Escherichia hermanii which was NSF also performed by inoculation of each microorganism in the KCN broth medium as Escherichia. hermanii can grow in the presence of KCN while SNF STEC can not grow. Another test for differentiation between these two microorganism was cellobiose fermentation test in which Escherichia hermanii ferment cellobiose leading to color exchange from red to yellow within $24 \mathrm{hrs}$ while NSF STEC showed negative result. On the other hand, rhamnose fermentation can also be used in the differentiation between rhamnose fermenter E.hermanii and sorbitol negative STEC which was non-rhamnose fermenter.

\section{PCR technique}

The DNA of all isolates was extracted and purificated by using genom DNA purification kit. The results were detected by electrophoresis on $1 \%$ agarose gel and exposed to U.V light in which the DNA appear as compact bands. The results of PCR amplification which was performed on the DNA extracted from all the studied isolates confirmed by electrophoresis analysis. By this analysis the strands of DNA which are resulted from the successful binding between specific $\mathrm{Stx}_{2}$ primers of STEC and isolates extracted DNA. These successful binding appear as single band under the U.V light using ethidium bromide as a specific DNA stain. The electrophoresis also used to estimate DNA weight depending on DNA marker (100 bp DNA ladder )and the result of this estimation revealed that the amplified DNA of all STEC had 346 bp (Figure 4-6). The results of PCR revealed that only $16(10 \%)$ STEC isolates of bovine feces and 2 (1.6\%) STEC isolated from children stool samples were PCR-positive for $\mathrm{Stx}_{2}$ (Table 2).

Table 2 :Distribution of NSF, STEC and Stx2 gene in fecal sample of children and cattle

\begin{tabular}{|l|c|c|c|c|c|c|c|c|l|}
\hline \multirow{2}{*}{ Isolates sources } & Total & \multicolumn{2}{|c|}{ NSF } & \multicolumn{2}{|c|}{ STEC } & \multicolumn{2}{|c|}{ PCR } & \multirow{2}{*}{ X $^{2}$} & \multirow{2}{*}{ P- value } \\
\cline { 1 - 5 } & & No. & $\%$ & No. & $\%$ & + ve & $\%$ & & \\
\hline Children & 120 & 69 & 57.5 & 5 & 4.16 & 2 & 1.6 & 91.6 & $0.01 *$ \\
\hline cattle & 160 & 140 & 87.5 & 38 & 23.75 & 16 & 10 & 85.05 & 0.01 \\
\hline Total & 280 & 209 & 74.6 & 43 & 15.35 & 18 & 6.42 & \multicolumn{2}{c|}{ df $=2$} \\
\hline
\end{tabular}

$* \mathrm{P}<0.01$

\section{Detection of Enterohemolysin production}

In comparative study between Shiga toxin production and enterohemolysin activity concordance positive results between both were $16(88.9 \%)$. Concordance negative results were zero $(0.0 \%)$. Negative results for Shiga toxin production and positive for enterohemolysin was zero (Table3).The positive reported enterohemolytic activity was for positive results after $24 \mathrm{hrs}$. 
Table 3 : Comparism between $\mathrm{STX}_{2}$ production versus enterohemolysin.

\begin{tabular}{|c|c|c|c|c|c|c|c|c|}
\hline \multirow{2}{*}{$\mathrm{STX}_{2}$ production } & \multicolumn{2}{|c|}{$\begin{array}{l}\text { Enterohemolysin } \\
\text { positive }\end{array}$} & \multicolumn{2}{|c|}{ Enterohemolysin negative } & \multicolumn{2}{|c|}{ Total } & \multirow[t]{2}{*}{$\mathrm{X}^{2}$} & \multirow[t]{2}{*}{ P-value } \\
\hline & NO. & $\%$ & No. & $\%$ & No. & $\%$ & & \\
\hline Positive No. & 16 & 88.9 & 2 & 11.1 & 18 & 100 & \multirow{2}{*}{47.1} & \multirow{2}{*}{0.01} \\
\hline Negative No. & 0 & 0 & 0 & 0 & 0 & 0 & & \\
\hline Total No. & 16 & 88.9 & 2 & 11.1 & 18 & 100 & \multicolumn{2}{|c|}{$\mathrm{df}=1$} \\
\hline \multicolumn{7}{|c|}{$\begin{array}{ll}\mathrm{X}^{2} \text { value }(\text { calculated })=30.77 & (\mathrm{p}<0.01) \\
\mathrm{X}^{2} \text { value }(\text { Tabulated })=6.63 & \end{array}$} & & \\
\hline
\end{tabular}

\section{Discussion}

In the present study NSF E. coli was isolated on selective enrichment trypticase soy broth supplemented with cefixime and vancomycin (TSB-CV). This medium permits growth of $E$. coli and inhibit a wide range of contaminants including Proteus spp. (11).Also the enrichment method is necessary for the increment of bacteria to the level in which easily detected as low infection dose (100 cell) as well as limited amount of Shiga toxin (1peco gram) were able to cause infection (11). SMAC represents the most common medium used for the isolation of NSF $E$. coli as they can not able to ferment sorbitol their growth on this medium appear as colorless colonies which distinguished them from the majority of fecal $E$. coli belonging to other serotypes (12). Supplementation of this medium with ( $5 \mathrm{~g} /$ liter) of rhamnose help in the differentiation between rhamnose fermenter E. hermanii which is also NSF and NSF STEC which grow as transparent colony . Presence of tellurite SMAC increase its selectivity as this material has inhibition effect on contaminants. The goal of the present study was to identify STEC and to ascertain its detection rate from other NSF $E$. coli in the fecal samples of children with diarrhea and carrier cattle .The method used to identify STEC include classical biochemical tests for $E$. coli, specific

\section{References}

\footnotetext{
1. World Health Organization. (1991).
Programme for control of diarrheal
disease: interim programme report

1. World Health Organization. (1991).
Programme for control of diarrheal
disease: interim programme report

1. World Health Organization. (1991).
Programme for control of diarrheal
disease: interim programme report
}

biochemical tests for STEC, Hi25 Enterobacteriaceae identification kit and PCR detection method. According to these methods the present results revealed that (5) STEC isolates $(4.16 \%)$ out of (69) NSF isolated from children fecal samples.In the present study the frequency of STEC isolated in cattle feces was $(23.7 \%)$. The use of DNA probe (13) , synthetic oligonucleotide probe (14) and amplification of $V T$ gene by polymerase chain reaction (PCR) (15) and (16) were developed firstly for molecular diagnosis of diarrheagenic $E$. coli In the present study we used pre enrichment phase followed by subculturing on selective medium (SMAC) and testing of a set of colonies by biochemical tests , confirmed by PCR amplification with $\mathrm{Stx}_{2}$ specific primer.In order to establish a rapid identification of STEC whatever its serotypes we used enterohemolysin production as a surrogate marker in the present study . Enterohemolysin was detected in $16(88.8 \%)$ of STEC that carry Stx gene. STEC hemolysin which causes an enterohemolytic phenotype on blood agar was detected in many STEC strains of different origins in previous reports (17).That's to say enterohemolysin production could be considered as a good phenotypic marker of STEC.

1990. Document WHO / CDD 191.36. World Health Organization, Geneva. 
2. Doyle, M. P.; Zhao, T.; Meng, J. and Zhao, S. (1997). Escherichia coli O157:H7 .In food microbiology: Fundamentals and Frontiers .pp:171-191.

3. Karmali, M. A. (1989). Infection by verocytotoxin - producing Escherichia coli. Clin. Microbiol. Rev., 2(1): 15-38.

4. Stephan, R. and Untermann, F. (1999). Virulance factors and phenotypical traits of verotoxin - producing Escherichia coli strains isolated from asymptomatic human carriers. J. Clin. Microbiol., 37(5): $1570-$ 72.

5. Quinn, P.J.; Markey, B.K.; Carter, M.E.; Donnelly, W.J.C. and Leonard, F.C. (2006). Veterinary Microbiology and Microbial Disease, Blackwell Science Publishing Britain.

6. Su, C. and Brandt, L.J. (1995).

Escherchia coli O157:H Infection inHumans. Ann. Intern. Med. 123: 698-711.

7. Fukushima, H.; Hoshina, K. and Gomyoda, M. (2000). Selective isolation of eae-positive strains of shiga toxin producing Escherichia coli. J. Clin. Microbiol. 38: 155158.

8. Beutin, L.; Montenegro, M. A.; Orskov, I.; Orskov, F.; Prada, J.; Zimmermann, S. and Stephan, R. (1989).Close association of verotoxin (shiga toxin) production with enterohemolysin in strains

9. MacFaddin, J. F. (2000). Biochemical tests. For identification of medical bacteria $\left(3^{\text {rd }} \mathrm{ed}\right)$, Lippincott Williams and wilkins, USA.

10. Collee, J. G.; Fraser, A. G.; Marion, B. P. and Simmons, A. (eds)(1996). Mackie and McCaraty Practical
Medical Microbiology. $14^{\text {th }}$ ed. Longman Singapore.Pp:131-149.

11. Reissbrodt, R. (1998). Enterohemorrhagic Escherichia coli. isolation and identification. Biotest Bulletin., 6: $65-74$.

12. Goldwater, P. N. and Bettelheim, K. A. (1996). An outbreak of hemolytic uremic symdrom due to Escherichia coli $\mathrm{O} 157: \mathrm{H}^{-}$.Emerg. Infect. Dis. 2(2): 153-154.

13. Newland, J.W. and Neill, R.J. (1988). DNA probes for shiga like toxins I and II and for toxin converting bacteriophages. J. Clin. Microbiol. 26: 1292-1297.

14. Brown, J., Sethabutr, O.; Jackson, M.; Lolekha, S. and Echeverria P. (1989). Hybridization of Escherichia coli producing shigalike toxin I, shiga-like toxin II, and a variant shiga like toxin II with synthetic oligonucleotide probes. Infect. Immun. 57:1811-1814.

15. Pollard, D. R.; Johnson, W. M.; Lior, H.; Tyler, S. D. and Rozee, K. R. (1990). Rapid and specific detection of verotoxin genes in Escherichia coli by the polymerase chain reaction. J. Clin. Microbiol. 28: $540-545$.

16. Brain, M. J.; Frosolono, M.; Murray, B. E.; Miranda, A.; Lopez, E. L.; Gomez, H. F. and Cleary, T. G. (1992). Polymerase chian reaction for diagnosis of enterohemorragic Escherichia coli infection and hemolytic uremic syndrome. J. Clin. Microbiol. 30: 1801-1806.

17. Harnitzky, M.A.; Vanselow, B.A.; Walker, K.; Bettelheim, K.A.; Corney, B.; Gill, P.; Bailey, G. and Djordjevic, S.P. (2002). Virulance properties and serotypes of shigatoxin-producing Escherichia coli from healthy Australian cattle. Appl. Environ. Microbiol. 68: 6439-6445. 
AL-Qadisiya Journal of Vet.Med.Sci $\quad$ Number of $4^{\text {th }}$ conference $24-25$ Nov. 2010

\section{الكشف عن جرثومة الأشريشيا القولونية المنتجة لأيفان الشيكا المعزولة من

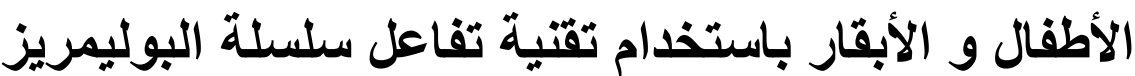 \\ عدنان حمد عبيد \\ فوزية علي عبد الله

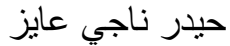 \\ كلية الطب البيطري / جامعة القادسية كلية الطب البيطري / جامعة البصرة كلية الطب / جامعة القادسية \\ الخلاصة الناطري}

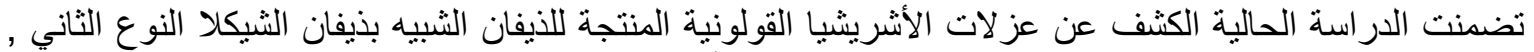

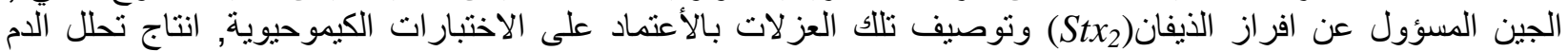

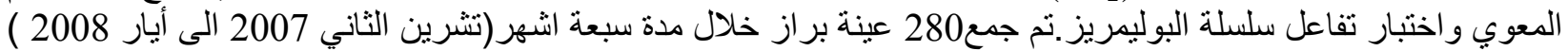





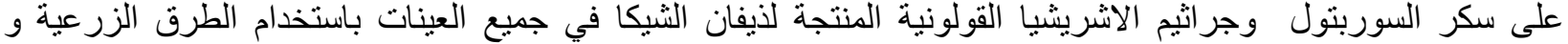

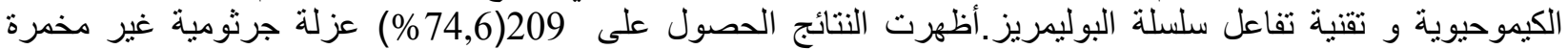

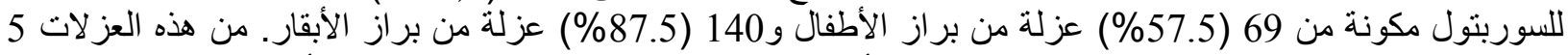

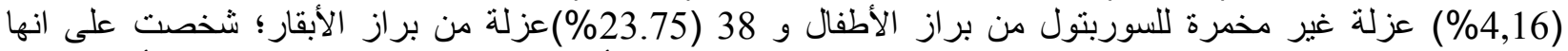



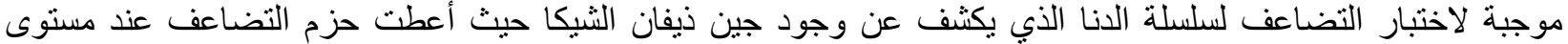

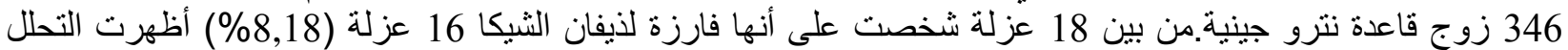

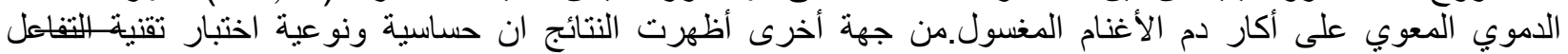

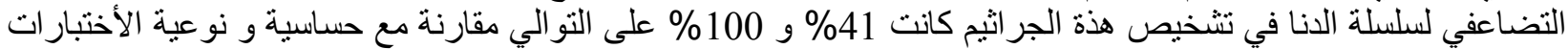
الكيموحيوية و التي كانت 100\% و 86\% على التو الي. 